\title{
SURVEI PARAMETER FISIKA-KIMIA PERAIRAN DAN KONSENTRASI LOGAM BERAT PADA KERANG HIJAU DI PULAU REKLAMASI C DAN D, TELUK JAKARTA
}

\author{
Salmita Salman \\ Fakultas Pertanian Universitas Islam Riau \\ email:salmitasalman@agr.uir.ac.id
}

\begin{abstract}
ABSTRAK: Survei perlu dilakukan untuk memperoleh informasi konsentrasi logam berat di habitat buatan dan biota laut. Tujuan dari penelitian ini adalah mengidentifikasi faktor fisika-kimia lingkungan perairan terkait kehadiran logam berat dan mengidentifikasi kandungan logam berat pada kerang hijau (Perna viridis) di sekitar Pulau Reklamasi. Pengambilan sampel di lapangan dilakukan pada bulan Agustus 2017 di Pulau Reklamasi C dan D. Pengukuran nilai logam berat mengacu pada metode SNI 3554-2015. Data dianalisis secara deskriptif kuantitatif terhadap parameter-parameter fisika-kimia perairan dan kandungan logam berat pada kerang hijau. Hasil penelitian menunjukan kebutuhan oksigen biologi (BOD), kebutuhan oksigen kimiawi (COD) telah melebihi baku mutu air yang menunjukkan tingginya tingkat pencemaran. Hasil pemeriksaan logam berat pada air laut menunjukkan bahwa merkuri $(\mathrm{Hg})$, kadmium $(\mathrm{Cd})$, dan timbal $(\mathrm{Pb})$ berada di bawah batas deteksi alat yang digunakan $(<0,0002 ;<0,00011 ;<0,00086 \mathrm{mg} / \mathrm{L})$ dan di bawah baku mutu air laut untuk biota. Konsentrasi logam berat merkuri, kadmium dan timbal pada sedimen di sekitar Pulau Reklamasi masih berada di bawah baku mutu logam berat pada sedimen. Kadar logam berat merkuri $(\mathrm{Hg})$ di bawah batas deteksi alat $(<0,0004$ $\mathrm{mg} / \mathrm{L})$; kadmium $(\mathrm{Cd})$ berkisar antara 0,02-0,20 mg/L; timbal $(\mathrm{Pb})$ berkisar antara 0,50-5,46 mg/L. Hasil pemeriksaan logam berat pada kerang hijau menunjukkan bahwa merkuri $(\mathrm{Hg})$, kadmium $(\mathrm{Cd})$, dan timbal $(\mathrm{Pb})$ berada di bawah batas deteksi alat yang digunakan $(<0,009 ;<0,00011 ;<0,00086 \mathrm{mg} / \mathrm{L})$ dan dibawah baku mutu logam berat pada jenis kerang-kerangan.
\end{abstract}

Kata kunci: merkuri, kadmium, timbal, pulau reklamasi

ABSTRACT: Surveys need to be conducted to obtain information on heavy metal content in man-made habitat and biota. The purposes of this research are to identify physical-chemical factors of the aquatic environment related to the presence of heavy metals and to identify the content of heavy metals in green mussels (Perna viridis) around the Reclamation Island. Field sampling was conducted in August 2017 in Reclamation Islands C and D. Measurement of heavy metal values refers to the SNI method 3554-2015. Data were analyzed with quantitative descriptive on the physical-chemical parameters of seawater and the content of heavy metals in green mussels. The results show biological oxygen demand (BOD), chemical oxygen demand (COD) had exceeded the water quality standard which indicates high level of pollution. The results of the examination of heavy metals in seawater show that mercury $(\mathrm{Hg})$, cadmium $(\mathrm{Cd})$, and lead $(\mathrm{Pb})$ are below the tools detection limit (<0,0002; <0,00011; <0,00086 $\mathrm{mg} / \mathrm{L})$ and below water pollution standards for biota. Concentrations of heavy metals mercury, cadmium, and lead in sediments around the reclaimed islands area are 
below heavy metal pollution standards for sediments. Mercury $(\mathrm{Hg})$ levels below the tools detection limit $(<0.0004 \mathrm{mg} / \mathrm{L})$; cadmium $(C d)$ ranges from 0.02-0.20 $\mathrm{mg} / \mathrm{L}$; lead $(\mathrm{Pb})$ ranges from 0.50 to $5.46 \mathrm{mg} / \mathrm{L}$. Heavy metals examination in green mussels indicate that mercury $(\mathrm{Hg})$, cadmium $(\mathrm{Cd})$, and lead $(\mathrm{Pb})$ are below the tools detection limit (<0.001; <0.00011; $<0.00086 \mathrm{mg} / \mathrm{L})$ and below the heavy metal pollution standard on bivalves.

Keywords: mercury, cadmium, lead, reclamation island

\section{PENDAHULUAN}

Salah satu tujuan reklamasi pulau dalam Peratutan Daerah Provinsi DKI Jakarta adalah untuk memenuhi kebutuhan lahan dengan pertimbangan populasi penduduk akan terus meningkat. Penelitian pemodelan oleh (Badriana, 2015; Aprilia dan P., 2017) menyatakan bahwa terjadi penurunan nilai kecepatan arus rata-rata setelah diadakan reklamasi, perubahan kecepatan arus terjadi di celah dan sekitar area reklamasi dan peningkatan sedimen berpotensi muncul di sekitar area reklamasi bagian dalam/dekat pesisir dan di celah antar pulau reklamasi.

Perubahan arus di sekitar Pulau Reklamasi akan menurunkan waktu retensi dalam mencuci kontaminan yang masuk dari daratan. Hal ini mengakibatkan peningkatan laju sedimentasi di sekitar muara, eutrofikasi, dan penumpukan bahan pencemar diantaranya logam berat. Penelitian yang berhubungan dengan pencemaran logam berat di perairan Teluk Jakarta yang sudah pernah dilakukan sebelumnya menunjukkan bahwa telah terdeteksi logam berat dengan kadar yang bervariasi (Cordova, 2011; Putri et al., 2012; Permanawati et al., 2013; Suryono, 2006).

Kerang hijau bersifat menetap (sesil), menempel pada substrat menggunakan bissus, dan filter feeder yang memungkinkan logam berat di perairan ikut masuk ke dalam tubuh kerang hijau (Cordova et al., 2016). Kerang hijau mampu mengikat logam dan menyimpannya dalam tubuhnya dengan efektif (Dumalaganan et al., 2010), sehingga kerang hijau direkomedasikan sebagai biofilter logam berat (Koropitan dan Cordova, 2017). Saat ini, tidak ada informasi tentang kandungan logam pada kerang hijau yang hidup di habitat pulau reklamasi C dan D. Berdasarkan kondisi tersebut, survei kandungan logam berat pada kerang hijau dan habitatnya diperlukan. Dengan demikian tujuan dari penelitian ini adalah untuk mengidentifikasi kualitas air yang terkait dengan keberadaan logam berat dan untuk mengukur kandungan logam berat dalam kerang hijau (Perna viridis) di sekitar pulau reklamasi.

\section{METODE PENELITIAN}

Penelitian ini dilakukan dari Juli hingga Desember 2017. Stasiun pengambilan sampel ditentukan secara purpossive berdasarkan pada kehadiran kerang hijau di titik pemantauan biota yang terlampir dalam Rencana Pengelolaan Lingkungan dan Rencana Pemantauan Lingkungan (RKL-RPL) Pulau Reklamasi C dan D (stasiun A, B, C, dan D pada gambar 1) serta satu stasiun sampling di daerah Teluk Naga sebagai pembanding. Ada tiga titik pengamatan di setiap stasiun, ditandai dengan Global Positioning System (GPS). sampling dilakukan pada bvulan Agustus 2017 dan diharapkan memberikan 
gambaran kondisi perairan pada musim kering. Metode penelitian deskriptif digunakan untuk menentukan kadar logam berat dalam kerang hijau. Kerang hijau dikumpulkan dengan teknik handsorting (Abdulgani dan Aunurohim, 2010).

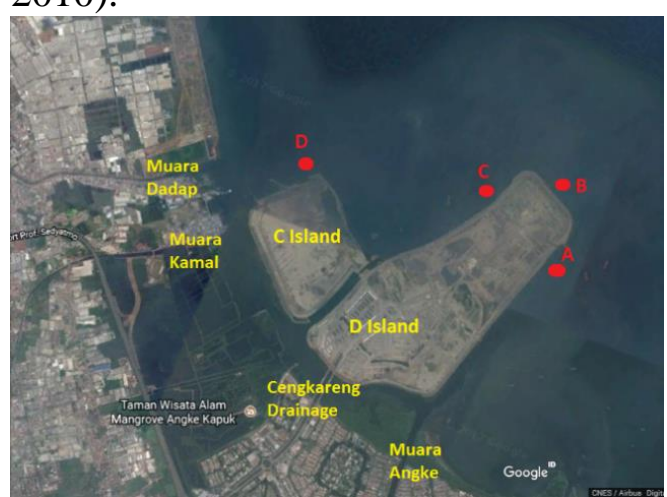

Gambar 1. Stasiun sampling di sekitar pulau C dan D

Alat yang digunakan dalam penelitian ini meliputi water sampler, sediment sampler, botol plastik polietilen $500 \mathrm{ml}$ dan $250 \mathrm{ml}$, Global Positioning System (GPS) Garmin GPSMAP64s, coolbox, plastik klip, gelas kimia, pipet, meteran, $\mathrm{pH}$ meter, refraktometer, turbidimeter, oven, corong, kertas label, timbangan analitik, DO meter, kamera, saringan bertingkat, Alat inductively coupled plasma optical emission spectrometry (ICP-OES). Bahan yang digunakan antara lain kerang hijau (Perna viridis), sampel air, sampel sedimen, aquades, pengawet sampel $\left(\mathrm{H}_{2} \mathrm{SO}_{4} \quad 86 \%\right.$, $\mathrm{HNO}_{3} \quad 70 \%$ ). Pengambilan dan penanganan sampel mengacu pada Puget Sound Water Quality Action (PSWQA) (PSWQA., 1997) dan Standar Nasional Indonesia (SNI) 06-2412-1991 (SNI, 2008).

Data diambil termasuk pengukuran parameter fisika dan kimia air. Pengukuran dilakukan secara in-situ atau ex-situ melalui analisis laboratorium dan dilakukan tiga kali pengukuran pada masingmasing titik pengamatan. Pengukuran in-situ diantaranya kedalaman, suhu, $\mathrm{pH}$, salinitas dan oksigen terlarut (DO). Pengukuran ek-situ analisis ukuran butir dilakukan di Laboratorium Ekologi Sekolah Ilmu dan Teknologi Kehidupan Institut Teknologi Bandung (SITH ITB). Pengukuran total padatan tersuspensi (TSS), kebutuhan oksigen biologi (BOD), kebutuhan oksigen oksigen kimiawi (COD), dan logam berat dilakukan oleh laboratorium Saraswanti Indo Genetech (SIG) Bogor. Tekstur sedimen ditentukan berdasarkan pada (K., 1922) dengan menyaring sedimen menggunakan saringan bertingkat. Jenis sedimen ditentukan menggunakan Segitiga Miller (Miller dan White, 1998). TSS, Sampel sedimen dan kerang hijau disimpan pada $4{ }^{0}$ C. Sampel BOD disimpan dalam botol gelap pada $4{ }^{0} \mathrm{C}$. Sampel COD disimpan dengan menambahkan $\mathrm{H}_{2} \mathrm{SO}_{4}$. Sampel air diawetkan dengan $\mathrm{HNO}_{3}$.

\section{HASIL DAN PEMBAHASAN}

3.1 Logam Berat di Air Laut dan Sedimen

Hasil analisis sampel logam berat merkuri $(\mathrm{Hg})$, kadmium $(\mathrm{Cd})$, dan timbal $(\mathrm{Pb})$ di dalam air dan sedimen Pulau Reklamasi dan Teluk Naga disajikan pada Tabel 1. Ke-tiga logam berat pada air berada di bawah baku mutu air laut berdasarkan Keputusan Menteri lingkungan hidup no. 51 tahun 2004 sehingga relatif aman bagi biota laut. Hasil ini sesuai dengan penelitian Putri et al. (2012) yang menyatakan konsentrasi logam berat merkuri, kadmium dan timbal di perairan muara kamal berada di bawah baku mutu air laut sehingga 
air masih cocok untuk pertumbuhan

Konsentrasi

kerang dan biota lainnya.

Tabel 1. Data pengamatan parameter fisika-kimia air dan konsentrasi logam berat

\begin{tabular}{|c|c|c|c|c|c|c|c|}
\hline No. & Parameter & $\bar{A}$ & $\mathrm{~B}$ & $\mathrm{C}$ & $\mathrm{D}$ & $\mathrm{TN}$ & Standard Quality \\
\hline \multicolumn{8}{|l|}{ Air } \\
\hline & \multicolumn{7}{|l|}{ Fisika } \\
\hline 1 & Kecerahan (m) & 0,9 & 1,8 & 1,4 & 0,9 & 1,7 & $\begin{array}{l}\text { Coral: }>5 ; \text { mangrove: } \\
- \text {; seagrass: }>3 \text {; } \\
\text { natural }>0,5\end{array}$ \\
\hline 2 & Turbiditas (NTU) & $10,5^{*}$ & $7,0^{*}$ & 4,5 & $8,3^{*}$ & $5,5^{*}$ & $<5$ \\
\hline 3 & $\begin{array}{l}\text { Total padatan } \\
\text { tersuspensi }(\mathrm{mg} / \mathrm{L})\end{array}$ & 9,3 & 7,3 & 8,3 & 13,0 & 3,6 & 20 \\
\hline 4 & Sampah & - & - & 3 & 5 & - & Nihil \\
\hline \multirow[t]{3}{*}{5} & Suhu $\left({ }^{0} \mathrm{C}\right)$ & 28,9 & 28,7 & 29,0 & 29,1 & 30,2 & Natural (20-30) \\
\hline & \multicolumn{7}{|l|}{ Kimia } \\
\hline & $\mathrm{pH}$ & 8,4 & 8,6 & 8,6 & $8,9^{*}$ & 8,6 & $7-8,5$ \\
\hline 1 & Salinitas (\%o) & $29,3^{*}$ & 30,0 & 30,1 & 30,2 & 30,8 & Natural (30-40) \\
\hline 2 & DO (mg/L) & $3,89^{*}$ & $4,70^{*}$ & $4,67^{*}$ & $4,55^{*}$ & 5,16 & $>5$ \\
\hline 3 & $\mathrm{COD}(\mathrm{mg} / \mathrm{L})$ & $70,0^{*}$ & $85,1^{*}$ & $71,2^{*}$ & $79,6^{*}$ & $81,7^{*}$ & 20 \\
\hline 4 & BOD (mg/L) & $265,3^{*}$ & $474,8^{*}$ & $373,8^{*}$ & $593,2 *$ & $418,2^{*}$ & 20 \\
\hline 5 & Merkuri (mg/L) & $\mathrm{td}$ & $\mathrm{td}$ & $\mathrm{td}$ & $\mathrm{td}$ & td & 0.001 \\
\hline 6 & Kadmium (mg/L) & $\mathrm{td}$ & $\mathrm{td}$ & $\mathrm{td}$ & $\mathrm{td}$ & $\mathrm{td}$ & 0.001 \\
\hline 7 & Timbal (mg/L) & $\mathrm{td}$ & $\mathrm{td}$ & $\mathrm{td}$ & $\mathrm{td}$ & $\mathrm{td}$ & 0.008 \\
\hline \multicolumn{8}{|c|}{ Sedimen } \\
\hline 1 & Merkuri (mg/L) & $\mathrm{td}$ & $\mathrm{td}$ & $\mathrm{td}$ & $\mathrm{td}$ & $\mathrm{td}$ & 0.03 \\
\hline 2 & Kadmium (mg/L) & 0.14 & 0.07 & 0.08 & 0.15 & 0.09 & 0.8 \\
\hline 3 & Timbal (mg/L) & 3.19 & 2.29 & 2.10 & 4.62 & 2.50 & 85 \\
\hline \multicolumn{8}{|c|}{ Kerang Hijau } \\
\hline 1 & Merkuri (mg/l) & $\mathrm{td}$ & $\mathrm{td}$ & $\mathrm{td}$ & $\mathrm{td}$ & td & 1 \\
\hline 2 & Kadmium (mg/l) & $\mathrm{td}$ & $\mathrm{td}$ & $\mathrm{td}$ & $\mathrm{td}$ & $\mathrm{td}$ & 1 \\
\hline 3 & Timbal (mg/l) & $\mathrm{td}$ & $\mathrm{td}$ & $\mathrm{td}$ & td & $\mathrm{td}$ & 1.5 \\
\hline
\end{tabular}


- Baku Mutu Air Laut Untuk Biota Laut berdasarkan Keputusan Menteri Lingkungan Hidup No. 51 tahun 2004. Batas deteksi alat untuk merkuri (Hg) 0,0002 mg/L; kadmium (Cd) 0,00011 mg/L; timah $(\mathrm{Pb})$ 0,00086 mg/L.

- Baku mutu logam berat pada sedimen berdasarkan IADC/CEDA. Batas deteksi alat untuk merkuri (Hg) 0,0004 mg/L.

- Baku mutu berdasarkan SNI 7387:2009 tentang batas maksimum cemaran logam berat dalam pangan. Batas deteksi alat untuk merkuri $(\mathrm{Hg})$ 0,009 mg / L; kadmiun (Cd) 0,00011 mg / L; timbal (Pb) $0,00086 \mathrm{mg} / \mathrm{L}$

logam berat pada kawasan ekosistem perairan berkaitan dengan keberadaan logam berat alami di alam dan limbah logam berat dari sisa industri yang masuk ke kawasan tersebut. Konsentrasi logam berat semakin tinggi dengan masukan limbah ke perairan dan akan terakumulasi di ekosistem. Menurut Warner dan Preston (1974); HP. (1984) Logam berat yang masuk ke dalam ekosistem perairan akan mengalami berbagai proses diantaranya sedimentasi, dilusi, dispersi dan absorpsi oleh organisme pada ekosistem perairan tersebut.

Konsentrasi merkuri (Hg) dalam sedimen sekitar Pulau Reklamasi dan Teluk Naga tidak berbahaya bagi lingkungan dan organisme perairan. Konsentrasi merkuri $(\mathrm{Hg})$ di daerah penelitian mungkin rendah sehingga tidak terdeteksi. Konsentrasi kadmium (Cd) dalam sedimen berkisar antara 0,07-0,15 $\mathrm{mg} / \mathrm{L}$. Nilai konsentrasi berada di bawah standar IADC (International Association of Drilling Contractors)/CEDA (Central Dredging Association) (1997). Kadmium (Cd) pada konsentrasi itu tidak memiliki potensi bahaya bagi organisme perairam. Analisis $\mathrm{Cd}$ menunjukkan konsentrasi sedimen yang lebih tinggi dari kolom air di setiap lokasi penelitian. Ini terjadi karena logam berat memiliki kecenderungan untuk menyelesaikan karena dari massa besar. Konsentrasi timbal $(\mathrm{Pb})$ sedimen berkisar 2,104,62 mg/L. Nilai konsentrasinya di bawah standar IADC/CEDA (1997). Keberadaan logam $\mathrm{Pb}$ di sedimen diduga karena tingginya konsentrasi partikel organik dan anorganik di perairan (CC et al., 2007; Begum et al., 2009). Ph sedimen yang lebih rendah dibandingkan dengan $\mathrm{pH}$ air juga dapat menyebabkan konsentrasi $\mathrm{Pb}$ lebih besar di sedimen. Hal ini sesuai dengan pernyataan $\mathrm{S}$ dan $\mathrm{MH}$ (2010) bahwa proses adsorpsi logam berat oleh sedimen sejalan dengan penurunan nilai $\mathrm{pH}$.

Kandungan logam berat pada sedimen secara umum dipengaruhi oleh konsentrasi bahan organik, ukuran butir, dan mineralogi. Konsentrasi logam berat yang tinggi umumnya berasosiasi dengan sedimen bertekstur lempung dan liat $(<63 \mu \mathrm{m})$ (SE., 2001). Tekstur sedimen di Pulau Reklamasi terutama berupa pasir yang mungkin menjadi salah satu alasan rendahnya konsentrasi logam berat. Kandungan kadmium dan timbal dalam sedimen lebih besar daripada di air laut tetapi di bawah baku mutu sedimen. Kadar logam berat logam berat merkuri, kadmium dan timbal di masingmasing stasiun dapat dikatakan tidak membahayakan organisme laut. Permanawati et al. (2013) menyatakan bahwa konsentrasi logam berat (tembaga (CU), timah $(\mathrm{Pb})$, seng) (Zn), kadmium (Cd), dan kromium (Cr)) pada air dan sedimen di perairan teluk Jakarta di bawah baku mutu.

\subsection{Logam Berat di Kerang Hijau}


Tabel 1 menunjukkan konsentrasi logam berat merkuri $(\mathrm{Hg})$, kadmium $(\mathrm{Cd})$, dan timbal $(\mathrm{Pb})$ pada kerang hijau tidak terdeteksi dan berada di bawah standar pencemaran logam untuk bivalvia menurut Badan Standarisasi Nasional (BSN) 7387 (SNI, 2009). Merkuri, kadmium, dan timbal yang terkandung dalam air dan sedimen belum melebihi baku mutu yang ditentukan. Ini menunjukkan bahwa konsentrasi logam berat tidak mencemari lingkungan meskipun Teluk Jakarta memiliki potensi tercemar yang tinggi. Akumulasi konsentrasi logam berat pada kerang hijau dapat terjadi karena logam berat masuk ke dalamnya tubuh organisme hidup dengan mudah dan cepat (de Astudillo L. R. et al., 2005). Namun pada penelitian ini berhasil tidak terjadi akumulasi merkuri ( $\mathrm{Hg})$, kadmium $(\mathrm{Cd})$, dan timah $(\mathrm{Pb})$ pada kerang hijau. Ini adalah mungkin karena rendahnya konsentrasi merkuri ( $\mathrm{Hg}$ ), kadmium (Cd), dan timbal $(\mathrm{Pb})$ dalam air dan sedimen.
Akumulasi logam berat pada organisme akuatik menurut (SE., 2001) dipengaruhi oleh banyak faktor, di antaranya:

- Konsentrasi logam berat dalam air

- Konsentrasi logam berat dalam sedimen

- Keasaman air dan sedimen

- Tingkat kebutuhan oksigen kimiawi (COD) dalam air

- Kandungan belerang dalam air dan sedimen

- Jenis organisme akuatik

- Umur organisme dan berat badan serta

- Fase kehidupan organisme (telur, larva)

Hal di atas yang menyebabkan jika konsentrasi logam berat tinggi dalam air maka konsentrasi logam berat pada sedimen akan tinggi. Saat konsentrasi logam berat sedimen tinggi, maka akumulasi konsentrasi logam berat dalam tubuh hewan laut terutama yang bersifat sesil akan tinggi (K. et al., 2004; IDL dan SM., 1996).

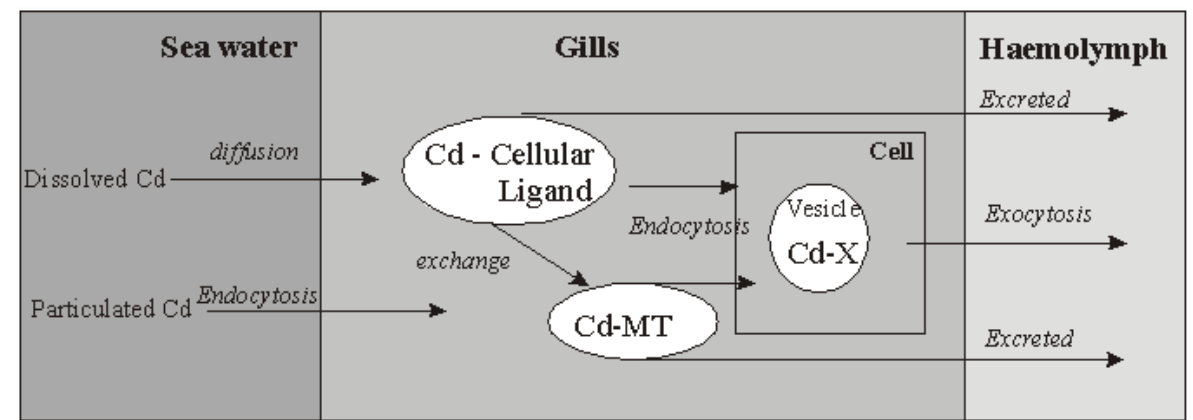

Gambar 2: Mekanisme akumulasi dan detoksifikasi logam berat oleh bivalvia

(Soto et al., 2003) 
Logam-logam berat memasuki sel melalui lapisan lipid pada membran sel secara endositosis. Logam beran non esensial yang masuk ke dalam sel akan berkompetisi dengan logam berat esensial untuk berikatan dengan ligan. Mekanisme pengikatan logam oleh protein umumnya merusak ikatan sulfida (N. et al., 2004). Logam berat pada ikatan sulfida akan memyebabkan kerusakan protein. Logam berat yang berikatan dengan biomolekul ini selanjutnya akan terakumulasi di hepatopankreas atau didetoksifikasi. Mekanisme akumulasi dan detoksifikasi logam berat oleh bivalvia dapat dilihat pada Gambar 2. Logam berat memodifikasi enzim, mengganggu serta menggantikan ion kalsium $\left(\mathrm{Ca}^{2+}\right)$ sehingga mempengaruhi proses oksidasi. Dalam penelitian ini logam berat merkuri $(\mathrm{Hg})$, kadmium (Cd), dan timbal $(\mathrm{Pb})$ dari sampel kerang hijau terdapat dalam batas yang dapat diterima kerang hijau dan predatornya. Ini dapat diamati dari tidak adanya akumulasi logam berat pada kerang yang menunjukkan bahwa kadmium $(\mathrm{Cd})$ dan timah $(\mathrm{Pb})$ dalam sedimen yang memasuki sel tubuh telah didetoksifikasi.

\section{KESIMPULAN}

Berdasarkan hasil tersebut dapat disimpulkan bahwa:

- Konsentrasi merkuri (Hg), kadmium (Cd) dan timbal $(\mathrm{Pb})$ dalam air di bawah baku mutu air untuk biota. Konsentrasi merkuri $(\mathrm{Hg})$, kadmium $(\mathrm{Cd})$ dan timbal $(\mathrm{Pb})$ dalam sedimen di bawah standar IADC/CEDA. Konsentrasi logam berat dalam air dan sedimen Pulau Reklamasi C dan D aman untuk biota. Konentrasi kebutuhan oksigen biologi (BOD) dan kebutuhan oksigen kimiawi (COD) menunjukkan polusi organik yang tinggi sekitar pulau reklamasi C dan D

- Tidak ada akumulasi logam berat merkuri (Hg), kadmium (Cd), dan timbal $(\mathrm{Pb})$ pada kerang hijau di sekitar Pulau Reklamasi C dan D.

\section{REFERENSI}

Abdulgani, N. dan Aunurohim, A.W. I. (2010). Konsentrasi Kadmium (Cd) Pada Kerang Hijau (Perna viridis) di Surabaya dan Madura. Berk Penel. Hayili Edisi Khusus: 4F.

Aprilia, E. dan P., D. G. (2017). Pemodelan hidrodinamika 3-dimensi pola persebaran sedimentasi pra dan pasca reklamasi teluk jakarta. Jurnal Teknik ITS, 6(2).

Badriana, R. M. (2015). Variasi Medan Kecepatan Arus Musiman Pada Rencana Pembangunan Reklamasi Jakarta. ITB: Skripsi.

Begum, A., Ramaiah, M., Khan, I., Veena, K., et al. (2009). Heavy metal pollution and chemical profile of cauvery river water. Journal of Chemistry, 6(1):4752.

CC, A., NP, O., EE, O., dan UG., I. (2007). Some physicochemical characteristics and heavy metal profiles of nigerian rivers, streams and waterways. Afr J Biotechnol, 6(5):617-624.

Cordova, M. R., Purbonegoro, T., Puspitasari, R., dan Hindarti, D. (2016). Assessing contamination level of jakarta bay nearshore sediments using green mussel (perna viridis) larvae. Mar. Res. Indonesia, 41:67-76.

Cordova, R. M. (2011). Akumulasi logam berat pada kerang

hijau (perna viridis) di perairan teluk jakarta. Jurnal Moluska Indonesia, 2:1-8.

de Astudillo L. R., C., Y. I., dan I., B. (2005). Heavy metals in sediments, mussels and oysters from trinidad and venezuela. Int. J. Trop. Bio., 53(1):41-53.

Dumalagan, H., Gonzales, A., dan Hallare, A. (2010). Trace metal content in mussels, perna viridis 1., obtained from selected seafood markets in a metropolitan city. Bulletin of environmental contamination and toxicology, 84(4):492-496.

HP., H. (1984). Logam berat dalam lingkungan laut. Pewarta Oceana IX, 1:1219. 
IDL, F. dan SM., C. (1996). Heavy metals in the hydrological cycle: trends and explanation.

K., W. C. (1922). A scale of grade and class terms for clastic

sediments. The Journal of Geology 30, 5:377-392.

K., Y. C., A., I., dan G., T. S. (2004). Biomonitoring of heavy metals in the west coastal of peninsular malaysia using the green-lipped mussel perna viridis,

present status and what next? pertanika. J. Trop. Agric. Sci., 27(2):151-16.

Koropitan, A. F. dan Cordova, M. R. (2017). Study of heavy metal distribution and hydrodynamic simulation in green mussel culture net, cilincing water-jakarta bay. Makara Journal of Science, 21(2).

Miller, D. A. dan White, R. A. (1998). 1998: A conterminous united states multi-layer soil characteristics data set for regional climate and hydrology modeling. Earth Interactions, 2.

N., A., V., R. T., dan D., K. R. (2004). Biosorption of Heavy Metals. Bangalore, Indian Institute of Science.

Permanawati, Y., Zuraida, R., dan Ibrahim, A. (2013). Kandungan logam berat (cu, pb, zn, cd dan cr) dalam air dan sedimen di perairan teluk jakarta. Jurnal Geologi kelautan, 11(1).

PSWQA. (1997). Recommended guidelines for sampling marine sediment, water column, and tissue in puget sound.
For. U.S. Environmental Protection Agency Region 10.

Putri, L. S. E., Prasetyo, A. D., dan Arifin, Z. (2012). Green Mussel (Perna viridis L.) as Bioindicator of Heavy Metals Pollution at Kamal Estuary jakarta bay, indonesia. J. of Environmental Research and Development, 6(3):389-396.

S, D. dan MH., B. (2010). Industrial pollution and heavy metals profile of challawa river in kano. Nigeria. $\mathbf{J}$ Appl Sci Envi Sanitation, 5(1):23-29.

SE., M. (2001). Fundamental of Environmental Chemistry. Lewis Publishers: United State of America.

SNI, B. (2008). Cara Uji Penentuan Kadar Air untuk Tanah dan Batuan di Laboratorium. Jakarta: BSN.

SNI, B. (2009). Batas Maksimum Cemaran Logam Berat dalam. Makanan, SNI, 7387:2009.

Soto, M., M., I., and C., I. (2003). Biological Aspects of Metal Accumulation and Storage. University of the Basque Country: Bilbo.

Suryono, C. A. (2006). Kecepatan Filtrasi Kerang Hijau Perna viridis terhadap Skeletonema sp pada Media Tercemar Logam Berat Timbal $(\mathrm{Pb})$ dan Tembaga $(\mathrm{Cu})$. Ilmu Kelautan, 11(3):153 157.

Warner, M. L. dan Preston, E. H. (1974). A review of environmental impact assessment methodologies, volume 3 . Office of Research and Development, US Environmental Protection Agency: for.. 